\title{
In The Context of Cipp Model: A Case for Re-Engineering Higher Education in Nigeria for Employment and Productivity
}

\author{
Femi Daniel, PhD \\ Department of Educational Psychology Islamic University in Uganda, Mbale, Uganda
}

\begin{abstract}
There is a growing concern about the quality of the products of our tertiary institutions. There is equally a concern about the high level of unemployment, especially of graduates of our various institutions. Using the Content, Input, Process, Product (CIPP) model as the guide, the paper discusses how positioned higher education in Nigeria is in meeting its mandate of manpower development for employment and expected productivity levels. It observes that the input resources and process components fall short of what is ideal. It equally observes that the internal and external environmental contexts in which higher education is given is not suitable for producing quality graduates that are employable and productive even if employed. The paper therefore recommends an overhaul of higher education and re-orientation of the academic courses, community and the larger society in such a way that permits closer ties.
\end{abstract}

\section{Introduction}

Education is the means by which knowledge, skill and attitude are largely transmitted from one generation to another. One of Nigeria's educational goals, derived from the main national goals, is the acquisition of appropriate skills and development of physical, social abilities and competencies of the society (Federal Government of Nigeria, 2004).

Bamiro (2012) has a rather ambitious and idealistic view of what a university education function should be and captures it thus:

A university should move radically from brewing graduates looking for employment to be seen as crucial national assists on addressing many policy prorates and as sources of new knowledge and innovative thinking; providers of skilled personnel and credible credentials contributors to innovation; attraction of international talent and business investment; agent of social injustice and mobility contributors to social and cultural vitality and determinants of health and well-being.

This perception of the university role applies to a large extent to all categories of the nation's tertiary institutions including colleges of education, Polytechnic and monotechnic

A cardinal mandate of higher education of the nation is the production of high level power for national development that meets all of Bamiro,s goals. However, with regards to this role, there is a growing public concern among different groups: industrialists, educators, educationalists, employers, parents and government officials that the products of out higher institutions in recent times are below our expectations. This is coupled with the feeling in some quarters that many of the graduates of these institutions are not even employable.

According to Agih (2011), it is a fact that manpower production in Nigeria today is comparatively higher than any other time in the past, but this work force is seriously deficient in terms of required knowledge, skills and quality. He strongly believes that what is primarily responsible for this lapse among others is the poor quality of the products of our tertiary institutions of learning.

The effectiveness of any institution in discharging its duties depends to a very large extent on its quality. Recent ratings of Nigerian higher institutions, especially the universities, have been comparatively low at the global level. To ensure that the institutions turn out graduates of the expected quality, the institutions should be of reasonably high quality.

Tagoe (2011) strongly contend that the quality of institution is a sine qua non for its effectiveness in realizing its set goals. This paper makes a case or posits for re-engineering our higher education systems in order to make them adequately fit for the purpose of producing graduates that are both employable (by themselves and others) and productive to their employers.

\section{Concept Clarification}

There is a need to properly define the key terms of this paper. Engineering is the science-based profession and activity by which the physical forces of nature and properties of matter are made useful to human beings in the form of structure, machines (Encyclopedia Britannica, 2010); and process involved is done at a reasonable care. The field involves the application of science to the optimum conversion of the resources of nature to the uses of humankind. It involves bringing, knowledge to bear on practical problem in order to solve them. Engineering also involves conceiving, designing, creating, implementing apparatuses or process to solve 
economic, environmental or social problems. It is also used to create to improve end products applying scientific and technological principles. To re-engine is therefore an activity meant to restructure, rebuild or redesign a product or system perceived to be deficient in order to make it more useful, functional or appealing. It is essentially a re-approachment of the solution of human problem by devising a new method and means of converting available resources to use purposes.

Higher education is the third tie of the Nigerian educational system. It is a post-secondary level education that includes such categories as teacher education given at the colleges of education, technology education at Polytechnic/monotechnic and university education.

Employment simply implies a job or gainful work (Encyclopedia Britannica, 2010). It could mean working for another person (an employer, a business or an organization) that provides a job that pays a salary or wage. Or, it could be used to imply self-employment where one works for oneself. Maintaining a high level of employment has been a stated goal for many governments. Productivity, a related term, means the rate at which goods are made or services are rendered. The amount produced should take into cognize the work done, the time and money needed or invested. Productivity is contingent on the nature of the work force training and knowledge.

\section{The Working Model}

The working model is the Context Input, Process and Product (CIPP) because it offers explanation of the higher education schooling process schematically represented below in fig 1 as conceived by the researcher.

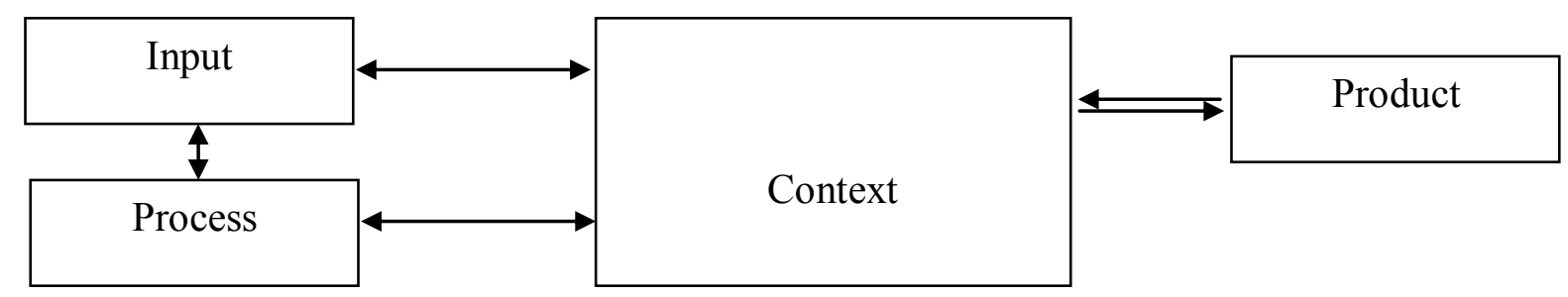

Fig 1 Interrelatedness of the CIPP components in the higher education industry

The diagram in fig. 1 shows the interrelatedness among three components (viz, input, process and context) that influence a fourth component, the products (or outcomes). The double edged arrow indicates a mutual influence between two components. While the two single arrows pointing at opposite directions indicate that though a reciprocity of influence is possible, but that is not often the case.

\section{Assessment of the Present State of Tertiary Institutions}

The quality of the inputs and effectiveness of process are directly related to the quality of products. Inputs into education are basically of three types: the material inputs, human resource inputs and financial resource inputs. The financial resource input influence the other input resources. For example, when funding is adequate, human resources and material resources input can be acquired in reasonable numbers and quality.

\section{Status of input components in higher education}

In Nigeria one of the major problems of education is inadequate funding (Agih, 2011). The budgetary allocations to education in general for over two decade have been consistently low, below the 26 percent of GDP CWE bench mark. This situation has been lamented (Ivowi, 2005: Agih, 2011). Onoriode (2005) believed that this problem of underfunding is even further compounded by the prevalent corruption in our society. These two prevailing situations leave the Nigerian higher institutions without the wherewithal to procure both human and non-human resources they need for effective operation.

The state of the material resources and human resources input has been decried, described largely and variously as non-available, inadequate or grossly lacking. For instance, Owolabi (1998) who described this situation as the poverty in resources input, believes human and material inputs into the system are grossly inadequate.

One of the obvious problems of the programme that tertiary institutions run is the shortfall of well qualified academic personnel. Ivowi (2006) indicated serious shortfalls in the number of qualified academic staff across Nigeria Universities in Agricultural Science, Engineering, Medicine, Science, Arts and L:aw faculties. Besides, the quality of the existing academics general falls below the minimum standards. Most academics do not have adequate exposure especially at the international level. Thus many of them lack the training and exposure that would acquaint them with current best practices, new techniques and knowledge. This situation gets worse as some of the experienced and more competent older academics retire; the junior ones 
who replace them are mostly the products of inbreeding and local institutions. This issue of the dearth of qualified academics appears even more serious in the colleges of education and polytechnics where $\mathrm{PhD}$ holders (consider to be the bench mark qualification for academics) are relatively fewer.

Another area of human resources input of concern is the quality of the intakes or entrants. Student input characteristics are skills, aspirations and other potentials for growth and learning that the students bring with them into the educational programme (Astin \& Panos, 1972). The inputs are in essence the human raw materials with which the educational programme has to deal. They normally include the student's personal characteristics as well as their value of school learning, the emphasis placed on effort and achievement. These characteristics are an important consideration in educational programme because the student's ultimate level of performance in terms of the relative output criteria may often be circumscribed by certain of his input characteristics no matter what the nature of the particular educational programme might be. The quality of the students and potential students on these characteristics is generally perceived to be poor. The results of public examinations such as Senior School Certificate Examinations (SSCE) and Unified Tertiary Matriculation Examination (UTME) characterized by poor performances do not seem to indicate the contrary. Despite that, one's personal examination experience shows that many of our students in higher institutions are merely after the certificates rather than the knowledge and skills such courses or schools offer.

The material inputs are many and various including the libraries, laboratories, workshops, facilities, infrastructure, and tools, equipment, other types of teaching and learning materials. The issues here are availability, condition of resources and their adequacy (where they are available). This is one area most directly affected by the level of funding. The general situation in this area is one of deficiencies, decay and currency. Ivowi (2006) paints a general poor picture of the facilities in laboratories and workshops for teaching purposes. According to him, there is also a general paucity of reference books in most universities and very limited sitting capacity. Given such a poor state of materials input, it would not be a surprise if delivery is instructions is hampered.

\section{State of process components in higher education}

This component describes the working of the system. It is the means or operation aimed to achieve programme goals. The teaching strategies, instructional approaches and pedagogical process are keys here.

The pedagogical process is a major aspect of the process components. Many of the academics of our tertiary institutions especially in the university and polytechnics are not certified in pedagogy. Though teaching is partly an art, but it also needs to be learned; thus training is required. The effectiveness of institution at this level owing to this factor alone cannot be assured. The prevalent mode of instruction in tertiary institutions is generally ineffective (Nwagwu, 2006). Emphasis is on theoretical approach rather than practical application (Nwana, 2006). Based on National University Commission (NUC) accreditation report, Nwana (2006) lamented that in certain professional disciplines, students do not have the appropriate levels of skills to enable them practice upon graduation. He notes that the system is not providing optimal laboratory/workshop opportunities for its students, has tended to down play the role of the practical example and over-emphasize the role of theory examination.

As for the curricular contents and policies, there is usually a problem with implementing it than their conceptualization (Maduewesi, 2007). In curricular development and implementation, there are hardly enough human resources, materials resources and time to implement them. A radical revamping of curricular to reflect world changes occasioned by the fast growth in technology should not be out of place.

The implementation process is also characterized by the examination mode that emphasizes theory, the ability to memorize and recall. The norm-reference test (NRT) being the predominant mode of assessing students achievement are well suited for assessing students broad level of knowledge and understanding of a subject not their mastering of a subject and skills nor their mastery of particulars (Daniel and Njoku, 2003). The advantages inherent in criterion-reference test (CRT) are often not exploited. In most disciplines, a forty percent pass benchmark does not encourage the students to learn to be good appliers of the knowledge they have acquired. It is clearly not enough for students to perform well in assessment, new skills keep coming up and higher institutions should equip their products to begin to think proactively (Afemikhe, 2005).

The management process of our higher education system in Nigeria is also generally ineffective (Nwagwu, 2006). Our campuses have become places of unending crisis of one form or the other. There tends to be a shift from management of human and material resources to management of crisis. There is consequently a distraction from the management aimed at achieving organizational goals, thus affecting the operational process in general. The crisis in the system has often affected the management of time available for teaching and learning. Time is essential in any production and products are affected if the optimum time for production cannot be afforded. This is probably one reason some feel that many our higher institutions graduates are halfbaked. Students and staff related crises in our higher institutions have had to result in the interruption and disruption of academic calendar. 


\section{Context component of higher education delivery}

The environmental context component consists of the internal and external environments. As part of the unsuitable internal environment, Afemikhe (2005) observed that classes are often too large. The internal environment of most tertiary institutions are characterized by perennial crisis, anti-social activities, sexual harassment, exploitation, extortion, cultism threat, accommodation problems, insecurity, examination malpractice, indiscipline among others. These factors precipitate an internal environment where academic activates can hardly thrive. Some of these factors are often disruptive of the flow of academic activities and programmes generally.

The external and internal environments are intricately related in a manner that the values of the large society are imposed on the internal environment of the institution, which affects its working. Our external environments are characterized by such vices and values that do not promote the operation of our high education system. Societal value placed on education is low and misplaced. Quest for money and material things overshadows quest for knowledge and skills which holds the promise the promise for national development.

\section{The Re-Engineering Needs in Higher Education}

The proceeding sections assessed the suitability of the Nigerian tertiary education system for the purpose of employability, employment creation and quality productivity. It can be inferred from the discourse that higher institution is generally and considerably in no good shape to deliver adequately on its mandate on employment and productivity. The brief, but critical assessment of the state of higher education, has shown that there are serious shortfalls, inadequacies, and ineffectiveness with respect to all three components, namely inputs, process, context and consequently substandard products. To address the system, we would need major re-engineering of all its individual components in order to improve the quality of its products. A substantial improvement of the products of our tertiary institutions would require a comprehensive, massive, in-depth reengineering of the entire higher education system would be required. The entire higher education system of the country needs to be refocused and redirected. A total overhaul of the system is obviously imperative.

\section{Conclusion}

This paper has indicated that higher education in its present form cannot deliver on its mandate to produce quality graduates that would be self-employed or highly employable as well as sufficiently productive. The inadequacies in the inputs and process components through an intervening unfavourable context cannot yield the kind of products that would meet the demands of the nation in terms of employment needs and productivity both now and in future.

\section{Recommendations}

There is an urgent need to substantially improve the inputs into the higher education sector particularly in the area of funding. We should at least try to meet the minimum UNESCO prescribed $26 \%$ of GDP allocation to education. This recommended financial input, if well managed would help to improve all other input elements into the system this would help to improve the lack of resources. Of course, the injection of fund into the system has to be complemented by prudent management of the resources.

There is also the serious need to expose the academics and supporting staff in the nation's schools to global best practices in higher education in order to meet our goals for our tertiary institutions. With these done, both the infrastructural and managerial processes would substantially improve to mitigate the unacceptably inefficiency in the operations of our schools.

The external and internal environments of the institutions which constitute the context component need also to be looked into through an effective national re-orientation programme. This is because the input and process components of the programme interact through a complex process within the environmental context of the institution to determine the quality of its products.

\section{References}

[1]. Afemikhe, O. A. (2005). Education for national re-engineering. Confluence Journal ofEducation, $2(1), 1-7$.

[2]. Agih, A. A. (2011). Quality issues in education and manpower development in Nigeria, National Association of Science, Humanities and Education Researcher Journal 9(1) June, 96-101.

[3]. Astin, A.W. \& Panos, R.J. (1972). The evaluation of educational programs. Washington: American Council of Education.

[4]. Maduewesi, E. (2003). Reforms in Nigeria Education. http//www.paddle.usp.ac.fi/paddle/cii-bin/paddle.ece.Retrieved 2 March, 2010 .

[5]. Daniel, F. \& Njoku, N.F. (2003). Introduction to educational measurement and evaluation. Ibadan, Safmos Publishers.

[6]. Federal Government of Nigeria (2004). National Policy on Education. Yaba-Lagos: NERDC.

[7]. Ivowi, U.M.O. (2005). An appraisal of knowledge in Nigerian tertiary institutions for the $21^{\text {st }}$ century. Keynote address delivered at the national conference on generation, quality assurance and dissemination of knowledge in Nigerian tertiary institutions for the $21^{\text {st }}$ century organized by the Institute of Education, University of Nigerian, Nsukka, May 17-21.

[8]. Ivowi, U.M.O (2006). Programme of tertiary institutions: Relevance and adequacy. In A. A. Aghenta (ed). Higher Education in Nigeria. Benin City: Ambik Press Ltd. 
[9]. Nwagwu, N.A. (2006). Critical issues in the management of students in Nigeria tertiary institutions. In A. A. Aghenta (ed). Higher Education in Nigeria. Benin City: Ambik Press Ltd.

[10]. Onoriode, E. (2005). Addressing the national development question in Nigeria through Economic/political reforms: privatization as a focus. A paper presented at the $1^{\text {st }}$ annual national conference of the School of Arts and Social Sciences, College of Education, Agbor.

[11]. Owolabi, S.L. (1998). Dimension of educational poverty in Nigeria. African Journal of Educational Management, 6, 197-208. 